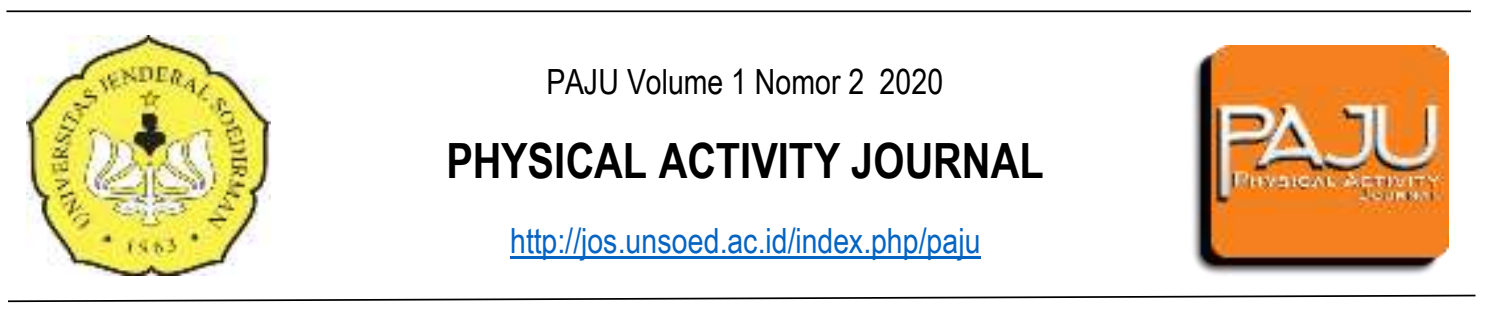

\title{
Pengaruh Latihan Skipping Terhadap Hasil Loncat Katak Pada Siswa Sekolah Dasar
}

\author{
Ibnu Sina ${ }^{1}$, Endri Pelariyanto² \\ 1,2 Jurusan Pendidikan Jasmani, Kesehatan dan Rekreasi STKIP Situs Banten, Indonesia \\ email: 1asebaacademy@gmail.com, 2endryyanto@gmail.com \\ DOI: https://doi.org/10.20884/1.paju.2020.1.2.2471
}

\begin{abstract}
Abstrak
Pembelajaran atletik di Sekolah Dasar memiliki bentuk berbeda dengan pola pembelajaran di SMP maupun SMA. Di Sekolah Dasar, atletik diajarkan dalam bentuk permainan Kids Athletic yang terdiri dari berbagai gerakan berlari, melempar dan meloncat. Materi meloncat diajarkan dalam bentuk Loncat Katak melalui berbagai metode pengajaran maupun metode latihan. Tujuan penelitian ini yaitu ingin mengetahui pengaruh latihan loncat tali terhadap hasil loncat katak pada siswa Sekolah Dasar. Penelitian mengunakan metode quasi eksperimen dengan desain One Group Pretest-Posttest Design. Populasi pada penelitian ini yaitu SD Negeri Simpang Tiga kelas V, sedangkan sampel yaitu SD Negeri Simpang Tiga kelas VB dengan jumlah 18 siswa putra dan 21 siswa putri total sampel yaitu 39 siswa, teknik sampling menggunakan cluster random sampling. Instrumen penelitian adalah tes Standing Board Jump (Nurhasan and Choli 2014) dengan validitas 0,607 dan reliabilitas 0,963. Hasil penelitian menunjukkan terdapat pengaruh latihan skipping terhadap hasil loncat katak siswa kelas V B SD Negeri Simpang Tiga dengan besarnya pengaruh yaitu sebesar $6.66 \%$ sedangkan $93.34 \%$ merupakan faktor lain yang tidak diteliti oleh peneliti. Kesimpulan dari penelitian ini yaitu salah satu metode latihan atau pembelajaran yang dapat digunakan bagi siswa Sekolah Dasar untuk meningkatkan hasil loncat katak (standing broad Jump) yaitu metode latihan skipping.
\end{abstract}

Kata kunci: Latihan, Skipping, Loncat Katak, Sekolah Dasar

\begin{abstract}
Athletic learning in elementary schools has a different form than the learning patterns in middle and high school. At elementary school, athletics are taught in the form of Kids Athletic games consisting of various movements of running, throwing and jumping. Jumping material is taught in the form of frog jumping through various teaching methods and training methods. The purpose of this study was to determine the effect of skipping training on frog jumping results in elementary school students. The study used an quasi experimental method with the design of One Group Pretest-Posttest Design. The population in this study is Simpang Tiga Elementary School Class V, while the sample is Simpang Tiga Elementary School VB class with a total of 18 male students and 21 female students total sample of 39 students, sampling technique using cluster random sampling. The research instrument was the Standing Board Jump test (Nurhasan and Hasanudin, 2014) with validity of 0.607 and reliability of 0.963 . The results showed that there was an effect of skipping training on frog jump learning outcomes of Class $V$ students of SD Negeri Simpang Tiga with a magnitude of
\end{abstract}


influence of $6.66 \%$ while $93.34 \%$ was another factor not examined by researchers. The conclusion of this study is one of the training or learning methods that can be used for elementary school students to improve the results of standing broad jump, the method of skipping training.

Keywords: Exercise, Skipping, Frog Jump, Elementary School

\begin{tabular}{|c|c|c|c|}
\hline Alamat Koresponden & : Jurusan PJKR STKIP Situs Banten & $\begin{array}{l}\text { e-ISSN } \\
p-I S S N\end{array}$ & $\begin{array}{l}: 2686-5807 \\
: 2686-5793\end{array}$ \\
\hline $\begin{array}{l}\text { E-mail } \\
\text { No.Telp } / \mathrm{Hp}\end{array}$ & $\begin{array}{l}: \quad \text { asebaacademy@gmail.com } \\
: \quad 085795703652\end{array}$ & & \\
\hline
\end{tabular}

\section{PENDAHULUAN}

Pendidikan jasmani menjadi komponen penting dalam mengembangkan aspek afektif, kognitif dan psikomotor bagi siswa disetiap jenjang sekolah. Menurut Mardiana, Purwadi, and Satya (2014) tujuan penjas adalah membina potensi anak melalui berbagai aktivitas fisik sehingga aspek fisik, motorik, mental, sosial dan emosional dapat berkembang secara optimal. Tujuan pendidikan jasmani dapat terlaksana apabila direncanakan secara sistematis dan disesuaikan dengan pertumbuhan perkembangan anak di setiap jenjang pendidikan baik Sekolah Dasar, Sekolah Menegah Pertama maupun Sekolah Menegah Atas.

Dalam pendidikan jasmani olahraga dan kesehatan terdapat beberapa materi yang diberikan kepada siswa di antaranya permainan, atletik, senam, renang (aktivitas air), olahraga tradisional dan aktivitas di luar kelas. Di tingkat Sekolah Dasar, pembelajaran atletik merupakan salah satu materi yang diajarkan kepada siswa, karena gerakan-gerakan pada pembelajaran atletik merupakan gerakan dasar yang dilakukan oleh anak sehari-hari. Menurut Ilham (2017) atletik merupakan aktivitas jasmani atau latihan fisik, yang memuat berbagai gerakan alamiah mirip dengan aktivitas yang dilakukan sehari-hari. Lebih lanjut atletik merupakan aktivitas jasmani yang terdiri dari gerakan dasar jalan, lari, lompat, dan lempar yang dinamis dan teratur (Hindriani, Sugiyanto, and Syafrial 2018).

Nomor-nomor dalam cabang olahraga atletik tersebut selalu diajarkan pada setiap jenjang pendidikan yang salah satunya yaitu nomor lompat. Dalam Pendidikan yang dilaksanakan pada tingkat Sekolah Dasar, materi nomor lompat pada atletik berubah menjadi loncat katak. Sesuai dengan KD 4.3 yang isinya menjelaskan tentang mempraktikkan pola gerak dasar dalam atletik nomor loncat, dan lempar melalui permainan/olahraga yang dimodifikasi dengan memperhatikan variasi dan kombinasi gerakan. Karakteristik dari permainan atletik untuk anak Sekolah Dasar yaitu diajarkan dalam bentuk permainan sehingga olahraga atletik tidak membosankan atau melelahkan (Rumini 2014). Lebih lanjut permainan atletik akan memberi anak-anak peluang untuk memanfaatkan sebaik-baiknya aktivitas atletik yang menguntungkan dalam aspek kesehatan dan pendidikan (IAAF, 2006). 
Berdasarkan kemampuan siswa Sekolah Dasar yang jauh berbeda dengan siswa Sekolah Menengah Pertama atau siswa Sekolah Menengah Atas, materi atletik di Sekolah Dasar diberikan melalui ativitas permainan dalam bentuk Kids Athletic. Pembelajaran kids athletic merupakan cabang olahraga atletik yang dikhususkan bagi anak-anak dengan tujuan melatih anak untuk belajar berkompetisi dalam berbagai permainan yang menggembirakan (Kurniyawan 2012). Kemudian Rumini (2014) pada anak usia 8-14 tahun alternatif pembelajaran atletik dilakukan dalam bentuk Kids' Athletics. Berdasarkan paparan teori maka pembelajaran kids athletics merupakan materi pembelajaran gerak yang fundamental bagi anak Sekolah Dasar.

Pembelajaran Kids Athletics yang diajarkan di tingkat Sekolah Dasar memiliki berbagai materi yang dapat diikuti oleh siswa. Permainan Kids' Athletics dibedakan dalam beberapa kelompok yaitu nomor lari, lompat dan lempar. Pada nomor lompat terdiri dari Lompat Galah, Lompat Tali (Rope Skipping), Loncat silang dan Loncat Katak (Rumini 2014). Dari beberapa nomor lompat dan loncat yang terdapat dalam kids athletics, loncat katak merupakan teknik yang penting untuk diajarkan serta dikuasai oleh siswa. Hasil penelitian Mudian (2018) menunjukan bahwa loncat katak dapat memberikan pengaruh pada daya ledak otot tungkai.

Loncat katak dapat didefinisikan sebagai gerakan meloncat-loncat ke depan dengan mengunakan kedua kaki secara bersamaan (Permadi 2015). Lebih lanjut, Kurniyawan (2012) menjelaskan loncat katak atau nama lainnya disebut sebagai loncat jongkok ke depan merupakan jenis cabang olahraga dalam atletik anak (Kids Athletic). loncat katak dilakukan dengan cara berdiri dengan kedua kaki kemudian berjongkok dan meloncat ke depan sejauh mungkin, mendarat dengan kedua kaki (IAAF, 2006). Oleh karena itu gerakan loncat katak penting untuk diajarkan kepada siswa Sekolah Dasar sebagai salah satu keterampilan gerak dasar olahraga bagi anak.

Pada kegiatan praktek loncat katak, siswa harus memiliki pengetahuan dan keterampilan dalam melakukan gerakan, akan tetapi tidak semua siswa dapat memahami dan melakukan gerakan loncat katak dengan baik. Berdasarkan data nilai yang peneliti peroleh dari guru PJKO pada materi loncat katak, menunjukan hasil kemampuan siswa SD Negeri Simpang Tiga dalam materi loncat katak memiliki hasil yang cukup rendah, dari jumlah siswa 39 anak menunjukan $74,4 \%$ nilai siswa berada di bawah Kriteria Kelulusan Minimum (KKM) pada materi loncat. Selain itu hasil obeservasi yang peneliti lakukan dalam proses belajar mengajar, rata-rata siswa memiliki kemampuan loncat katak yang rendah, minat berolahraga yang rendah terutama materi loncat katak, serta hasil belajar rata-rata kelas yang rendah.

Rendahnya kemampuan siswa Sekolah Dasar dalam melakukan gerakan loncat katak dapat disebabkan karena kurangnaya latihan berbagai gerakan dasar dalam olahraga. Hasil penelitian terdahulu menunjukan bahwa anak-anak sekolah PAUD di daerah Anyer menunjukan keterampilan motorik kasar pada kategori kurang yang mencapai 56,37\% (Alawiyah, 2014). Penelitian mengenai 
gerak dasar olahraga menunjukan bahwa 50\% siswa Sekolah Dasar di Bandung memiliki keterampilan gerak dasar olaraga (Fundamental Movement Skills) yang kurang, 30\% cukup dan hanya 20\% dalam kategori baik (Budi et al. 2019). Berdasarkan hasil penelitian tersebut maka perlu adanya metode latihan yang tepat bagi siswa Sekolah Dasar untuk meningkatkan keterampialn gerak olahraga, terutama pada gerakan loncat katak.

Metode latihan yang dapat digunakan salah satunya yaitu latihan loncat tali. Alasan mendasar dalam memilih metode loncat tali yaitu karena gerakan loncat tali memiliki kemiripan seperti gerakan loncat katak karena pada gerakan loncat tali, selain dapat melatih kekuatan dan power otot tungkai, juga dapat meningkatkan koordinasi serta keseimbangan yang semua komponen tersebut sangat dibutuhkan dalam melakukan gerakan loncat katak. Hasil penelitian terdahulu menunjukan program latihan loncat tali memiliki efek positif untuk meningkatkan kekuatan, VO2 max dan terutama kecepatan, sehingga dapat berkontribusi pada pengembangan keterampilan motorik anak-anak (Eler \& Acar, 2018). Loncat dengan tali adalah kegiatan yang penting dan mengarah pada peningkatan kekuatan serta power otot, kesehatan jantung, keseimbangan tubuh, kelincahan dan koordinasi di antara otot-otot tubuh (Grivedehi, Nourbakhsh, \& Sepasi, 2014). Berdasarkan karakteristik gerakan dan data penelitian terdahulu maka metode latihan skipping perlu diterapkan dalam upaya meningkatkan hasil loncat katak.

Loncat tali (skipping) yaitu sebuah gerakan meloncat melewati tali dari kepala hingga kaki yang dilakukan dengan kedua kaki secara bersama-sama (Ruliyadi 2015). Lebih lanjut Shandi (2019) bentuk pemanasan yang dapat digunakan dalam mempersiapkan otot-otot tubuh sehingga anak siap melakukan aktivitas olahraga dapat dilakukan dengan lompat tali. Dengan menerapkan metode latihan skipping (loncat tali) kepada siswa Sekolah Dasar maka diasumsikan mampu membantu meningkatkan keterampilan gerakan dasar dan meningkatkan komponen fisik yang dimiliki. Hasil penelitian menunjukan bahwa latihan skipping meningkatkan keterampilan koordinasi umum dan keseimbangan pada pemain sepak bola usia anak-anak. (Trecroci, Cavaggioni, Caccia, \& Alberti, 2015)

Latihan skipping pada anak Sekolah Dasar merupakan salah satu cara untuk membentuk kemampuan awal power otot tungkai yang dimiliki. Bounds, hops, jump dan leaps adalah beberapa jenis latihan lompat dan loncat yang dapat meningkatkan explosive power (kekuatan daya ledak) pada otot (Johan and Agustan 2017). Pada beberapa cabang olahraga yang memerlukan kompenen power, metode latihan loncat tali dapat digunakan untuk meningkatkan daya ledak (power) otot tungkai (Syaifudin 2015).

Hasil penelitian menunjukan prestasi siswa dalam lompat jauh dipengaruhi oleh gerak motorik kasar pada permainan lompat tali (Shandi 2019). Hasil penelitian lain menunjukan bahwa kemampuan dasar yang harus dimiliki pada olahraga atletik kids adalah kekuatan dan daya ledak otot (Johan and Agustan 2017). Metode latihan loncat tali yang diberikan dengan tepat, sesuai dengan karakteristik 
anak Sekolah Dasar diidentifikasi mampu meningkatikan hasil loncat katak pada siswa. Maka dari itu tujuan dari penelitian ini yaitu ingin mengetahui pengaruh latihan sklipping terhadap hasil loncat katak pada siswa Kelas V SD Negeri Simpang Tiga Kecamatan Purwakarta Kota Cilegon.

\section{METODE}

Penelitian menggunakan metode Quasi Eksperimen, Sugiyono (2016) mengemukakan bahwa Quasi Eksperimen bukanlah metode eksperimen murni, karena terdapat variabel luar yang ikut mempengaruhi hasil penelitian. Penelitian ini menggunakan desain One Group Pretest-Posttest Design, yang terdiri dari Pretest, Treatment) dan Posttest.

\begin{tabular}{|lll|}
\hline T1 & $\mathrm{X}$ & $\mathrm{T} 2$ \\
\hline
\end{tabular}

\section{Gambar 1 One Group Pretest-Posttest Design (Maksum 2012)}

Keterangan :

T1 : Pretest (Standing Broad Jump)

X : Treatment (Skipping)

T2 : Posttest (Standing Broad Jump)

Penelitian dilakukan selama 14 kali pertemuan dengan jumlah waktu latihan 3 kali dalam seminggu. Program latihan mengacu pada hasil penelitian terdahulu Afrizal (2018) bahwa Treatment yaitu dengan memberi perlakuan latihan loncat tali (skipping) dalam bentuk program mingguan yaitu: a) Lama perlakuan: 14 pertemuan, b) Frekuensi: 3x seminggu, c) Jumlah set: 3 set, d) Intensitas: $50-60 \%$, e) Durasi waktu: 10 menit, f) Recovery: 3 menit.

Populasi yang digunakan pada penelitian ini adalah siswa SD Negeri Simpang Tiga Pandeglang kelas V A dan B dengan jumlah 81 siswa dengan rata-rata usia 11 tahun. Sampel penelitian ini yaitu siswa kelas V B dengan menggunakan teknik Cluster Random Sampling Maksum (2012) yaitu memilih sampel penelitian berdasarkan kelas yang dipilih secara acak menggunakan undian, alasan menggunakan Cluster Random Sampling karena untuk mempermudah dalam pemberian treatment (perlakuan) serta dengan satu kelas yang terpilih dapat mewakili karakteristik siswa di kelas V SD Negeri Simpang Tiga Pandeglang, jumlah sampel penelitian sebanyak 39 siswa yang dapat di lihat pada tabel 1 berikut ini.

Tabel 1 Jumlah Sampel Penelitian

\begin{tabular}{|c|c|c|c|}
\hline Kelas & Putra & Putri & Sampel \\
\hline VB & 18 & 21 & \multirow{2}{*}{39} \\
\hline Total & & & \\
\hline
\end{tabular}


Instrumen penelitian adalah Standing Board Jump (Nurhasan and Cholil 2014) Untuk anak usia 10 tahun hingga mahasiswa, pria dan wanita dipakai untuk mengukur power tungkai, dengan cara meloncat ke depan. Koefisien validitas 0,607 dan reliabilitas 0,963 dengan kategori tinggi.

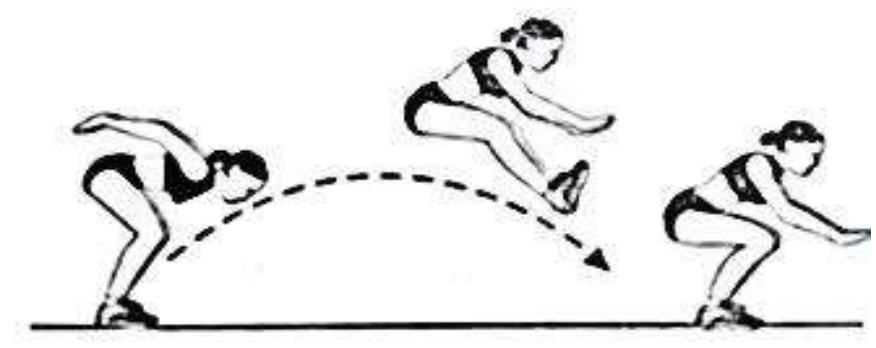

\section{Gambar 2 Tes Standing Board Jump}

Pelaksanakan tes dilakukan dengan cara, testee melakukan persiapan loncatan dengan berdiri di atas garis awalan dan tidak boleh melewati batas, kemudian lutut ditekuk hingga membentuk sudut $45^{\circ}$ kedua lengan lurus ke belakang dan meloncat sejauh mungkin dengan menggunakan kedua kaki serta mendarat dengan kedua kaki bersama-sama, data yang diambil adalah hasil loncatan terjauh setelah melakukan dua kali kesempatan (Nurhasan and Choli 2014). Teknik analisis data menggunakan aplikasi SPSS 25, dengan langkah-langkah sebagai berikut: Uji Normalitas dan Homogenitas Data. Dilakukan untuk mengidentifikasi apakah data penelitian berdistribusi normal atau tidak, apabila nilai $a>$ 0,05 maka data berdistribusi normal dan homogen. Uji Hipotesis menggunakan uji paired sampel $T$ test. Dilakukan untuk mengidentifikasi pengaruh dari treatment yang dilakukan terhadap hasil tes awal dan tes akhir, apabila nilai $a<0,05$ maka menunjukan adanya pengaruh.

\section{HASIL}

\section{Pengujian Normalitas Data}

Uji normalitas yang digunakan adalah uji kolmogorov-smirnov dengan bantuan SPSS versi 25 dengan signifikansi $a=0.05$. jika nilai sig. $>0.05$ maka data berdistribusi normal dan jika sig. $<$ 0.05 dapat dikatakan data tidak berdistribusi normal. Hasil perhitungan yang diperoleh dapat di lihat pada tabel 2 sebagai berikut:

Tabel 2 Uji Normalitas Data

One-Sample Kolmogorov-Smirnov Test

\begin{tabular}{llll} 
& & PreTest & Posttest \\
\hline $\mathrm{N}$ & & 39 & 39 \\
\hline Normal Parameters $\mathrm{a}, \mathrm{b}$ & Mean & 4.387 & 4.679 \\
\cline { 2 - 4 } & Std. Deviation & .6574 & .6963 \\
\hline \multirow{2}{*}{ Most Extreme Differences } & Absolute & .090 & .113 \\
\hline
\end{tabular}




\begin{tabular}{llll}
\hline & Positive & .083 & .094 \\
\cline { 2 - 4 } & Negative & -.090 & -.113 \\
\hline Test Statistic & & .090 & .113 \\
\hline Asymp. Sig. (2-tailed) & & $.200^{c, d}$ & $.200^{c, d}$ \\
\hline
\end{tabular}

Hasil uji normalitas di atas menunjukkan nilai signifikansi (Sig.2-tailed) skor pre-test loncat katak sebesar 0,200. Karena nilai signifikansi data di atas lebih besar dari 0,05 maka distribusi skor pre-test dan post-test hasil loncat katak berdistribusi normal.

\section{Pengujian Homogenitas Data}

Uji homogenitas yang digunakan pada penelitian ini menggunakan uji Test of Homogeneity of Variances, karena uji hipotesis yang digunakan pada penelitian ini menggunakan ANOVA pada taraf signifikansi $a>0.05$. data hasil analisis uji homogenitas dirangkum pada tabel 3 di bawah ini.

Tabel 3 Uji Homogenitas Data

Test of Homogeneity of Variances

\begin{tabular}{lll|l|l|l} 
& & Levene Statistic & df1 & df2 & Sig. \\
\hline Hasil Loncat katak & Based on Mean & .265 & 1 & 76 & .608 \\
\cline { 2 - 6 } & Based on Median & .263 & 1 & 76 & .610 \\
\cline { 2 - 6 } & $\begin{array}{l}\text { Based on Median and with } \\
\text { adjusted df }\end{array}$ & & 1 & 76.0 & .610 \\
\cline { 2 - 6 } & Based on trimmed mean & .250 & 1 & 76 & .619 \\
\hline
\end{tabular}

Berdasarkan hasil uji homogenitas data dapat dilihat bahwa nilai signifikansi (Based on trimmed mean) adalah 0,619, karena nilai tersebut >0,05 maka data penelitian bersifat homogen atau sama. Selanjutnya untuk melakukan pengujian hipotesis menggunakan statistik parametrik.

\section{Pengujian Hipotesis}

Pengujian hipotesis dilakukan untuk mengetahui apakah terdapat pengaruh dari latihan loncat tali (skipping) terhadap hasil loncat katak (standing broad jump) pada siswa Sekolah Dasar Kelas V. Untuk megetahui pengaruh tersebut maka dilakukan dengan uji-t sampel berpasangan atau uji Paired Samples T-Test dengan bantuan SPSS versi 25 , hasil pengujian dapat dilihat pada tabel 4 sebagai berikut. 
Tabel 4 Hasil Uji Paired Samples T-Test untuk Tes Awal dan Tes Akhir Loncat Katak

(Standing Broad Jump)

Paired Samples Test

\begin{tabular}{|c|c|c|c|c|c|c|c|c|c|}
\hline & & \multicolumn{5}{|c|}{ Paired Differences } & \multirow[b]{3}{*}{$\mathrm{T}$} & \multirow[b]{3}{*}{$d f$} & \multirow{3}{*}{$\begin{array}{l}\text { Sig. }(2 \\
\text { tailed })\end{array}$} \\
\hline & & \multirow[b]{2}{*}{ Mean } & \multirow{2}{*}{$\begin{array}{l}\text { Std. } \\
\text { Deviation }\end{array}$} & \multirow{2}{*}{$\begin{array}{l}\text { Std. } \\
\text { Mean }\end{array}$} & \multicolumn{2}{|c|}{$\begin{array}{l}95 \% \text { Confidence Interval } \\
\text { of the Difference }\end{array}$} & & & \\
\hline & & & & & Lower & Upper & & & \\
\hline $\begin{array}{l}\text { Pair } \\
1\end{array}$ & $\begin{array}{l}\text { PreTest } \\
- \\
\text { Posttest }\end{array}$ & .2923 & .1133 & .0181 & .3290 & .2556 & 16.114 & 38 & .000 \\
\hline
\end{tabular}

Diketahui pada tabel 5 nilai signifikansi pada peningkatan skor pre-test dan post-test hasil belajar loncat katak menunjukan angka $0,000<$ nilai (sig.) 0.05 sehingga terdapat pengaruh atau peningkatan latihan skipping terhadap hasil loncat katak siswa kelas V. Kemudian untuk mengetahui besarnya pengaruh latihan skipping terhadap hasil loncat katak dihitung menggunakan rumus dari (Sudjana, 2002) di bawah ini :

$$
\begin{aligned}
\text { Peningkatan } & =\frac{M_{D}}{M_{\text {pre }}} \times 100 \% \\
& =\frac{0,29}{4,39} \times 100 \%=6.66 \%
\end{aligned}
$$

Keterangan

MD : Rata-rata gabungan pretest dan postest

$M_{\text {pre }} \quad$ : Rata-rata skor pretest

Dari perhitungan di atas besarnya pengaruh yang diperoleh setelah siswa yang mendapatkan perlakuan latihan skipping adalah sebesar $6.66 \%$ sedangkan sebesar $93,4 \%$ berasal dari faktor lain yang tidak diteliti.

\section{Data Tes Loncat Katak (Standing Broad Jump)}

Data tes awal (pre-test) dan tes akhir (post-test) hasil loncat katak dengan latihan skipping (skipping) pada siswa Sekolah Dasar dapat di lihat pada tabel 5 sebagai berikut.

\section{Tabel 5 Hasil Tes Awal dan Tes Akhir Loncat Katak}

Descriptive Statistics

\begin{tabular}{lcccccc|c} 
& N & Minimum & Maximum & Sum & Mean & Std. Deviation \\
\hline PreTest & 39 & 2.5 & 5.8 & 171.1 & 4.39 & 0.66 \\
\hline Posttest & 39 & 2.9 & 6.3 & 182.5 & 4.68 & 0.70 \\
\hline Valid N (listwise) & 39 & & & & & \\
\hline
\end{tabular}

Data tes awal (pretest) loncat katak siswa SD Negeri Simpang Tiga Pandeglang Banten memiliki rata-rara hasil loncatan sejauh 4,39 meter dengan standar deviasi sebesar 0,66. 
Sedangkan pada tes akhir (posttest) loncat katak menunjukan hasil rata-rata loncatan sejauh 4,68 meter dengan nilai standar deviasi 0.70 . Bedasarkan data tes awal dan tes akhir maka terdapat peningkatan jumlah rata-rata hasil loncat katak yang dilakukan oleh siswa setelah melakukan latihan skipping.

\section{PEMBAHASAN}

Latihan skipping memberikan pengaruh dalam hasil loncat katak pada siswa Sekolah Dasar, yang terlihat dari adanya kenaikan skor rata-rata loncat katak dari tes awal ke tes akhir. Hal ini dikarenakan pada proses latihan, siswa melakukan gerakan skipping secara berulang-ulang dan karakteristik gerakan pada saat latihan hampir sama dengan gerakan loncat katak. Hasil penelitian ini mendukung hasil penelitian terdahulu yang dilakukan oleh Kurniyawan (2012) bahwa latihan loncat tali secara signifikan dapat meningkatkan kemampuan loncat katak (kids athletic) pada siswa Sekolah Dasar. Penelititian lain juga menunjukan hasil latihan lompat tali berpengaruh positif terhadap peningkatan hasil lompat jauh (Dwi 2018).

Secara karateristik gerakan pada latihan skipping, kedua kaki yang digunakan untuk meloncat secara bersama-sama harus dilakukan dengan cepat, hal ini dikarenakan putaran tali dari atas kepala hingga kaki dilakukan dengan cepat sehingga kontak kaki dengan lantai berlangsung dalam waktu yang singkat. Gerakan latihan pliometrik dilakukan dengan kecepatan gerak tertentu yang melibatkan refleks regang, dimana otot sudah berada dalam kedaan siap untuk berkontraksi lagi sebelum otot berada dalam keadaan rileks (Aziz and Yudi 2019). Lebih lanjut Radcliffe \& Farentino (2015) dalam Sin and Ruslin (2018) menjelaskan latihan plyometrik sering digunakan dalam menghubungkan lompatan berulang dan gerakan atau regangan-regangan refleks dari otot untuk menghasilkan reaksi daya ledak. Dengan karaktristik gerakan loncat tali yang mendekati gerakan dan prinsip latihan plyometrik maka latihan tersebut dapat meningkatkan power otot tungkai pada saat melakukan gerakan loncat katak pada siswa Sekolah Dasar.

Hasil penelitian memang menunjukan adanya peningkatan hasil latihan loncat tali terhadap kemampuan loncat katak siswa Sekolah Dasar, akan tetapi tingkat pengaruh tidak terlalu besar, hal ini dapat dikarenakan pada saat melakukan latihan loncat tali, siswa kurang fokus dalam prinsip gerakan loncat tali dengan mengacu pada karakteristik latihan plyometrik, seharusnya gerakan skipping pada saat kedua kaki kontak dengan lantai maka dengan segera harus kembali meloncat, akan tetapi banyak siswa pada sampel penelitian ini yang melakukan gerakan latihan skipping dengan lambat sehingga kontak kedua kaki dengan lantai terjadi pada waktu yang cukup lama, yang menyebabkan efek dari latihan kurang maksimal. Proses aktivitas loncat tali pada kids athletic, skor loncatan dihitung berdasarkan jumlah yang paling banyak selama 15 detik (IAAF, 2006). Hal ini menunjukan bahwa 
semakin banyak loncatan yang dilakukan oleh anak, maka skornya semakin baik, untuk dapat melakukan loncatan dengan jumlah yang cukup banyak maka harus dilakukan dengan cukup cepat.

Temuan lain yang diperoleh berdasarkan observasi selama proses latihan skipping, banyak siswa yang menjadi sampel penelitian belum memiliki kualitas gerakan yang baik sehingga latihan skipping tidak meberikan pengaruh yang besar pada hasil loncat katak. Rendahnya kualitas gerakan dasar olahraga yang dimiliki oleh anak-anak disebabkan oleh kurangnya aktivitas fisik yang dilakukan oleh anak-anak baik di sekolah maupun di lingkungan tempat tinggal (Budi et al. 2019).

Program latihan skipping apabila dilakukan dengan gerakan yang benar dan memperhatikan prinsip latihan plyometrik dengan pola gerakan cepat dan eksplosif maka pengaruh dari latihan loncat tali dapat lebih signifikan dalam meningkatkan power otot tungkai pada gerakan loncat katak. Oleh karena itu maka perlu adanya pengamatan dan evaluasi lebih detail pada saat siswa melakukan gerakan Iskipping, sehingga hasil latihan dapat lebih optimal.

\section{SIMPULAN}

Kesimpulan dari penelitian ini yaitu terdapat peningkatan dari skor pretest ke posttest setelah siswa melakukan latihan skipping tehadap hasil belajar loncat katak, dengan mengacu kepada hasil uji hipotesis yang menunjukkan nilai signifikansi pada peningkatan skor pre-test dan post-test hasil belajar loncat katak sebesar 0,000 , dengan nilai (sig.) $0.000<0.05$ yang artinya terdapat pengaruh atau peningkatan latihan skipping terhadap hasil loncat katak siswa kelas V B SD Negeri Simpang Tiga Pandeglang Banten. Disarankan untuk guru pendidikan jasmani dan pelatih dapat memberikan metode latihan skipping kepada anak Sekolah Dasar untuk dapat meningkatkan keterampilan loncat katak yang disesuaikan dengan karakteristik anak Sekolah Dasar dan berbasis keterampilan multilateral, sehingga anak dapat mengembangkan berbagai keterampilan gerak olahraga dengan baik. Pada penelitian selanjutnya dapat membandingkan antara metode latihan skipping dengan metode lainnya, seperti rope jump, box jump dan barrier hop jump sehingga akan diketahui tingkat efektifitas latihan, atau dapat juga dilakukan dengan jumlah sampel yang lebih banyak dan bervariasi.

\section{REFERENSI}

Alawiyah, R. T. (2014). Peningkatan Keterampilan Motorik Kasar Melalui Permainan Tradisional Banten. Jurnal Pendidikan Usia Dini, 8(1), 175-184.

Aziz, M., and A. Yudi. 2019. 'Perbedaan Pengaruh Latihan Pliometrik Dan Kecepatan Lari Terhadap Kemampuan Lompat Jauh Gaya Jongkok'. Jurnal Patriot 2(5): 1239-46.

Budi, Didik Rilastiyo, M. Nanang Himawan Kusuma, M. Syafei, and Mesa Rahmi Stephani. 2019. 'The Analysis of Fundamental Movement Skill in Primary School Student in Mountain Range'. 
Dwi, Dicky Reva Apriana Sanga. 2018. 'Pengaruh Latihan Lari Sprint Di Tanjakan Dan Lompat Tali Terhadap Peningkatan Hasil Lompat Jauh Pada Siswa SMA Negeri 1 Ciwaru'. Jurnal IImiah Educater 4(1): 36-44.

Eler, N., \& Acar, H. (2018). The effects of the rope jump training program in physical education lessons on strength, speed and VO 2 max in children. Universal Journal of Educational Research, 6(2), 340345 .

Grivedehi, M. B., Nourbakhsh, P., \& Sepasi, H. (2014). Effects Of Speedy and Demonstration JumpingRope Training on Gross Motor Skills. DAMA International, 3(4), 321-327.

Hindriani, Dita, Sugiyanto Sugiyanto, and Syafrial Syafrial. 2018. 'Analisis Kemampuan Kids Athletics Pada Siswa Sekolah Dasar di Kota Bengkulu'. KINESTETIK.

IAAF. (2006). Kids' Athletics : A Team Eevent for Children. International Association of Athletics Federations .

Ilham, Z. 2017. 'Hubungan Antara Daya Ledak Otot Tungkai Dengan Hasil Lompat Tinggi Gaya Straddle Siswa Putra Kelas X SMK YPS Prabumulih'. Jurnal IImu Keolahragaan 16(1): 12-21.

Johan, Dedi, and Boby Agustan. 2017. 'Pengaruh Penerapan Sport Education Model (SEM) Terhadap Hasil Belajar Atletik Kids'. JUARA : Jurnal Olahraga 2(1): 26-36.

Kurniyawan, Hafid. 2012. 'Meningkatkan Hasil Belajar Loncat Katak (Kids Athletic) Melalui Penerapan Alat Bantu Pembelajaran Pada Siswa Kelas IV SDN Wonowoso Surakarta Tahun Ajaran 2011/2012'. Jurnal Phederal Penjas 1(1).

Maksum, Ali. 2012. Metodelogi Penelitian Dalam Olahraga. Surabaya: Unesa University Press.

Mardiana, Ade, Purwadi, and W. I. Satya. 2014. Pendidikan Jasmani Dan Olahraga. Tangerang Selatan: Universitas Terbuka.

Mudian, Deni. 2018. 'Pengaruh Latihan Loncat Katak Dan Loncat Naik Turun Bangku Terhadap Kemampuan Lompat Jauh Gaya Jongkok'. BIORMATIKA Jurnal IImiah FKIP Universitas Subang $4(2)$.

Nurhasan, H, and Hasanudin D Cholil. 2014. Tes Dan Pengukuran Keolahragaan. Bandung: Universitas Pendidikan Indonesia.

Permadi, J. 2015. 'Pengaruh Peningkatan Latihan Loncat Katak Dan Naik Turun Bangku Terhadap Kemampuan Lompat Jauh'. Jurnal IImiah Penjas: 1-12.

Ruliyadi, S. 2015. 'Pengaruh Latihan Skipping Terhadap Peningkatan Power Otot Tungkai Pada Siswa Kelas X SMA Negeri 1 Way Pengubuan Lampung Tengah'. Jurnal IImiah Penjas 2(1).

Rumini. 2014. 'Pembelajaran Permainan Kids Athletics Sebagai Wujud Pengembangan Gerak Dasar Atletik Pada Anak-Anak'. Journal of Physical Education Health and Sport 1(2).

Shandi, Shutan Arie. 2019. 'Analisis Gerak Motorik Kasar Pada Permainan Lompat Tali Terhadap Prestasi Siswa Putra dalam Lompat Jauh Pada Kelas VIII SMP Negeri 2 Palibelo'. JURNAL ILMU KEOLAHRAGAAN.

Sin, Tjung Hauw, and Budi Indra Ruslin. 2018. 'Optimization of Achievement Motivation to Improve Long 
Jump Performance'. COUNS-EDU: The International Journal of Counseling and Education.

Sugiyono. 2016. 'Memahami Penelitian Kualitatif'. Bandung: Alfabeta.

Syaifudin, Wahyu. 2015. 'Pengaruh Latihan Skipping Terhadap Peningkatan Power Otot Tungkai Pada Siswa Kelas X SMA Negeri 1 Way Pengubuan Lampung Tengah'. Digital Repository Unila.

Sudjana. (2002). Metode Statistika. Bandung: Tarsito.

Trecroci, A., Cavaggioni, L., Caccia, R., \& Alberti, G. (2015). Jump rope training: Balance and motor coordination in preadolescent soccer players. Journal of Sports Science and Medicine, 14(2), 798798 